\title{
MÉTODOS AVALIATIVOS UTILIZADOS POR PROFESSORES DO CURSO DE LICENCIATURA EM COMPUTAÇÃO
}

\author{
Apresentação: Relato de Experiência \\ Marciene Pacheco ${ }^{1}$; Emanuela Vitória Dias Morais ${ }^{2}$; Albertina Marília Alves Guedes ${ }^{3}$ (Orientadora)
}

\section{INTRODUÇÃO}

Segundo Hoffmann (2003) a avaliação escolar deve ser percebida pelo professor como um conjunto de ações que poderá auxiliá-lo a refletir sobre as condições de aprendizagem oferecida no ambiente escolar e readequar quando necessário para atender às necessidades de aprendizagens dos alunos. Sant'anna (1995) destaca que o professor deve ter o cuidado em observar como se dá o desempenho escolar e processo de aprendizagem dos seus alunos visando. Segundo a Lei de Diretrizes e Bases da Educação (BRASIL, 1996, Art. 24), a verificação do rendimento escolar deve observar a avaliação contínua e cumulativa do desempenho do aluno, com prevalência dos aspectos qualitativos sobre os quantitativos e dos resultados ao longo do período.

Para Perrenoud (2002) o professor pode utilizar de estratégias de ensino diversas possibilitando que o aluno possa apreender e compreender o conteúdo ministrado em sala de aula de maneiras diferenciadas. Além disso, considerando que o professor exerce o papel de mediador dos conteúdos ministrados em sala de aula, Piletti (2010) apresenta que o papel do professor em sala de aula também consiste em ajudar o aluno a assimilar os conteúdos ministrados em sala de aula.

\section{RELATO DE EXPERIÊNCIA}

O presente relato diz respeito a uma experiência vivenciada por duas estudantes do curso de Licenciatura em Computação do IF Sertão PE, Campus Petrolina, durante as disciplinas cursadas até o $3^{\text {a }}$ período do curso de Licenciatura em Computação a qual teve como problemática: Quais são os métodos avaliativos utilizados por professores do curso de Licenciatura em Computação do IF Sertão, Campus Petrolina. Ressaltamos que como esse trabalho refere-se a um Relato de Experiência vivenciada pelas autoras não foi entrevistado nenhum professor e, por isso, não há análise de dados coletados.

\footnotetext{
${ }^{1}$ Estudante do curso de Licenciatura em Computação, IF Sertão PE, Campus Petrolina. E-mail: marcienepacheco@gmail.com ${ }^{2}$ Estudante do curso de Licenciatura em Computação, IF Sertão PE, Campus Petrolina. E-mail: vitoriadm98@gmail.com ${ }^{3}$ Professora do curso de Licenciatura em Computação, IF Sertão PE, Campus Petrolina. E-mail: albertina.guedes@ifsertao-pe.edu.br
} 
Mediante a participação nas aulas no referido curso, percebemos que os métodos de avaliação mais utilizados pelos professores do curso de Licenciatura em Computação são de cunho quantitativo em detrimento das avaliações qualitativas e assim demonstram que não valorizam os métodos avaliativos de cunho qualitativo no processo de ensinar e aprender.

A avaliação na concepção de Both (2007) está atrelada ao processo, onde se direciona a qualidade do desempenho sobre a quantidade de atividades propostas, tanto para o aluno quanto para o professor, ficando em um processo comparativo. Também percebemos que os procedimentos avaliativos não incoerentes com o objetivo proposto na disciplina visto que priorizam apenas o resultado e ignora como ocorre o processo de aprendizagem contradizendo o que é posto por Hoffmann (2003) quando apresentam que os resultados das avaliações aplicadas em sala de aula deve possibilitar que o professor faça uma reflexão sobre os métodos de avaliação que são utilizadas ao ministrar os conteúdos curriculares.

Algumas das principais avaliações quantitativas realizadas pelos professores são: avaliações teóricas de cunho decorativo; atividades que valorizam o embasamento teórico desconectado da perspectiva prática. Além disso, os professores solicitam atividades avaliativas confusas e quando os alunos executam as referidas atividades o professor ressalta que a atividade realizada pelos alunos não condiz com o que foi solicitado.

\section{CONSIDERAÇÕES FINAIS}

Diante dessa experiência percebemos a necessidade de mudanças nos processos avaliativos, fazendo o uso de estratégias de avaliação que visem romper com o modelo tradicional, priorizando a aprendizagem qualitativa e significativa. Além disso, é necessária a valorização do aluno como indivíduo diferenciado, em tempos e potencialidades distintas, as quais podem ser melhor avaliadas a partir de atividades qualitativas em detrimento de avaliações quantitativas.

\section{REFERÊNCIAS}

BOTH, I. J. Avaliação planejada, aprendizagem consentida: a filosofia do conhecimento. $1^{\mathrm{a}}$ Edição, Curitiba, PR: IBPEX, 2007.

BRASIL. Lei de Diretrizes e Bases da Educação, Lei nº 9.394, Art. 24, de 20 de dezembro de 1996. Disponível em: <http://www.planalto.gov.br/ccivil_03/leis/L9394.htm>. Acesso em: 13 set 2016.

HOFFMANN, J. Avaliação: mito e desafio. Uma perspectiva construtivista. $33^{\text {a }}$ Ed. Porto Alegre: Mediação, 2003.

PERRENOUD, P. A prática reflexiva e o ofício do professor: profissionalização e razão pedagógica In: Saber refletir sobre a própria prática: objetivo central da formação de professores. Porto Alegre: Artmed, 2002. 
SANT'ANNA, I. M. Por que avaliar? Como avaliar? Critérios e instrumentos. $12^{\mathrm{a}}$ Edição, Petrópolis, RJ: Vozes, 1995. 